\title{
VALUES OF ISLAMIC TEACHING IN CANDUNG KAWIK FOLKLORE
}

\author{
Sri Nursari, Slamet Subiyantoro, and Kundharu Saddhono \\ UNS Surakarta \\ Email: srinursari@student.uns.ac.id
}

\section{Abstract}

Folklore is part of the community. So that there is no extinction then done as documentation such as folklore Candung Kawik who came from Lampung. Folklore is currently less desirable and does not have a place from the community; therefore, the research is done so that the story still exists. The purpose of this study is to describe the values of Islamic teachings contained in Candung Kawik folklore. The method used to find the values of Islamic teachings is a descriptive qualitative method with content analysis. The primary data source in this study is Lampung folklore. The technique of data collection is done by literature study and recording. The result showed that there were eight values of Islamic teachings, namely faith, Islam, ihsan, taqwa, sincerity, trust, gratitude, and patience. All the values of Islamic education are obtained from the learning and actions of the characters in the story and can be used as learning material.

Cerita rakyat merupakan bagian dari kebudayaan masyarakat. Agar kebudayaan tidak punah maka dilakuakn suatu pendokumentasian seperti cerita rakyat Candung Kawik yang berasal dari Lampung. Cerita rakyat sekarang ini kurang diminati dan tidak mendapatkan tempat dari masyarakat, oleh karena itu dilakukan penelitian agar ceritanya masih ada. Tujuan dari penelitian ini untuk mendeskripsikan nilai-nilai ajaran Islam yang terdapat dalam cerita rakyat Candung Kawik. Metode yang digunakan untuk menemukan nilai-nilai ajaran Islam adalah metode kualitatif deskriptif dengan analisis isi. Sumber data primer dalam penelitian ini adalah cerita rakyat Lampung. Teknik pengumpulan data dilakukan dengan studi pustaka dan pencatatan. Hasil 
penelitian menunjukan ada delapan nilai-nilai ajaran Islam yaitu iman, islam, ihsan, taqwa, ikhlas, tawakal, syukur, dan sabar. Semua nilai-nilai pendidikan Islam didapat dari perilaku dan perbuatan para tokoh di dalam cerita dan dapat dijadikan bahan pembelajaran.

Keywords: Candung Kawik; folklore; Islamic teaching; values

\section{Introduction}

Candung Kawik is a story in the form of oral literature originating from Tanggamus regency, Lampung. The origin of the story of Candung Kawik was from the Semaka Bay. The entire research was carried out in Lampung area from 1980-1981 but was only published by the Ministry of Education and Culture in 1984. The four stories are in the collection of "Cerita Rakyat Daerah Lampung".

The collection of stories published has gone through the research process includes direct observation, interview, literature review, transcription, and translation into Indonesian. Transcription is done because the data taken is oral literature, so it needs to be converted into written form and translated into Indonesian because the direct speakers for folklore are native Lampung tribes who know the origin of the story.

Folklore included in the literary work in the form of oral literature because the speech is carried out directly passed down from generation to generation. Parents speak oral literature in daily life to their children, a grandfather to his grandchildren, a narrator to his listeners, a teacher to his students, or fellow members of the community (Indiarti, 2017). In this case, oral literature is distinguished from written literature, which is literature that is scattered with writing while oral literature is traditional. The oral literature in the form of tradition still exists today, it is giving a title to newly married boys, traditions ranging from the birth of a human child to death.

Oral literature and written literature are one part of Lampung tribal culture which is still preserved until now, However, the public does not know much folklore, although it has been transcribed into written form, many people, especially residents of Lampung do not know the story. That way the cultural heritage of the ancestors will disappear even though documentation has been carried out.

Not only in the community folklore is unknown, in education context such as schools in Lampung many students do not know the folklore of Lampung. 
Literary works in the form of folklore taught in schools are usually fixated with textbooks. The teacher rarely provides folklore material in the surrounding environment. The material given to students in all regions and even cities is the same, so the stories delivered are the same. In this case, the folklore that is in the book alone is well-known while the stories in other areas are still many with their story uniqueness. Aside from being a teaching material, it can also preserve the cultural results of the ancestors and education for its readers.

Ancient ancestors gave more examples through oral traditions such as storytelling. One such oral tradition is folklore. Usually, stories are read when children are going to sleep, after dinner, sitting together with families which makes oral traditions more sustainable. But in reality, now many folklore is unknown, especially the younger generation. Millennials now watch more soap operas, foreign films, more often access social networks via smartphones (Wiguna \& $\mathrm{Al}, 2018$ ). It can trigger oral traditions to be left along with the loss of speakers (Kurnianto, 2016). Therefore, according to Kristanto (2014), the existence of noble values contained in folklore should continue to be examined so that the younger generation can understand it.

The folklore that develops in an area in a particular society usually has a high educational value because it contains advice given by the ancestors verbally and hereditary (Al-Pansori \& Herman, 2014). Folklore not only functions as entertainment but also as an educational medium (Hakim, 2018). Kurniawan (2009) states that to instill education in children can be through folklore because it is unwittingly advantageous. Many folklore contains moral values and ancestral characters that can serve as role models in life (Setyawan et al., 2017). When carefully understood, folklore has an example and learning in it both through the characters in the story and direct narration.

One of the values of education in folklore is the value of Islamic teachings. Islam is spread through several media, such as in Java, that Islamic teachings are spread through puppet shows, songs, dances, and others. Folklore is also able to teach Islamic teaching because it is easier to teach only through a speech without the need for other media. Islam entered Lampung around the 15th century through three directions namely through West Lampung, Palembang, and Banten. From here, folktales begin stories that involve religious teachings as a medium for da'wah. Da'wah is carried out to spread Islam because not all Lampung residents embrace Islam. The religions that first came to Lampung were Hinduism and Buddhism, but over time the Islamic teachings came to the land of Lampung, brought by the chaplains of another region.

el Harakah Jurnal Budaya Islam Vol. 22 No. 1 Tahun 2020 
The entry of Islam in the archipelago greatly influenced the development of previous traditions and culture (Hartini, 2007). The prior development of Lampung's tradition and culture was believed in inanimate objects, superstition, or evil spirits. All the beliefs began to shift and lost as the entry of Islamic teachings into the archipelago, especially Lampung. Islam teaches what is wrong and right, so that the people of Lampung begin to say the shahada, perform prayers, study the Koran, establish places of worship such as mosques. Until now, Lampung people are famous for the Islamic religion, there is even a slogan that they should never be called the Lampung tribe if they are not Muslim. Until now, the native population of Lampung is mostly Muslim. The Indonesian nation is known as a religious and cultured nation, so religion and cultural education are vital (Yayah, 2017).

Some fundamental religious education values must be taught to a child. The types of religious values referred to by Madjid (2000) are faith, Islam, ihsan, taqwa, sincere, trust, gratitude and patience. Faith is an attitude of trust in Allah SWT. It is widely discussed in monotheism, which is divided into four types namely Ar-Rubuubiyah (Allah as creator God), Al-Uluuhiyah (Allah as a place of worship), Al-Asmaa (the oneness of Allah in names and attributes), Al-Mulkiyah (Allah as king/ruler) (Prayitno, 2005). Islam is human obedience, there are all Sharia laws taught by the Prophet Muhammad SAW (Muhammad, 2008). Ihsan is the application of worship based on the presence of God who always watches everywhere the eyes of the heart. In terminology, taqwa implies guarding against something that is against Allah SWT and carrying out His commands (Shihab, 2007). Ikhlas is a person's attitude just for the sake of getting the pleasure of Allah SWT without expecting something in return or reward (Damanhuri, 2010). Tawakal is the surrender of all to Allah, but before surrendering to do everything possible first then submit all right decisions, destiny from Allah (Al-Kaaf, 2001). Gratitude is an attitude of gratefulness to Allah for all that He has given. says Patience is every obstacle and temptation is carried out with courage and without complaining to achieve goals (Mubarok, 2001).

Religious education can be interpreted as an effort to shape personality according to Islamic teachings to students through teaching, guidance, or training in a formal or non-formal environment (Djamal, 2017). The existence of religious education is expected to provide guidance and lessons for children, especially in adolescents who are currently experiencing a moral decline. Many teenagers lack religious knowledge, but a lot of knowledge about the 
western world. Religion is only as a status of self if not studied and practiced seriously (Veronika et al., 2017). Case in point many children do violence against friends, parents, teachers and even strangers on the street. They were performing dishonorable actions such as cheating, offering, smoking, drinking. If left unchecked this will make the future of the nation's children destroyed.

The need for religious guidance can be taught by parents or teachers. Religious guidance can be taught informally as well as in non-formal environments. In formal contexts such as schools, folklore can be a learning material full of moral teachings. In non-formal context such as family environment, reading folktales before going to sleep will make children happy, familiarize the relationship between parents and children, and foster a sense of understanding.

There have been many studies on folklore in the archipelago using several different theories and objectives (Al-Pansori \& Herman, 2014; Gusal, 2015; Nurfitri, 2018; Sukrawati; 2015; Wiguna \& Al Ashadi, 2018). All these research on folklore assessed the value of character education from various regions in the archipelago. The research that is still relevant to this study is Isnaeni's (2018) carrying out religious civilization to shape the student's character behind the fading of religious values that shift with the development of the times resulting in moral damage. Then the research of Yunus (2015) concludes that religious/Islamic values can influence local effectiveness in society because Islam has become the majority that affects everyone in Indonesia, particularly in Bugis culture. What makes this research different from other research is in the field of Islamic values, especially in Lampung folklore. Not many people have researched Lampung folklore, therefore this research was conducted to find out the Islamic values contained in folklore.

Lampung, especially in Tanggamus regency has a lot of folklore, but most of the stories have never been used as children's reading material. The publication conducted by the Ministry of Education and Culture is the first step to document the legacy of ancestors, but if it is only in the form of paper/ documents without any other study as well as not able to preserve ancestral heritage. Accordingly, this research is held so that the ancestral heritage is maintained and can be taken positive values contained therein. Oral tradition exists to provide life lessons for future generations, but if it has no successors, it will become extinct. The purpose of this research is to examine the values of Islamic teachings contained in the Lampung folklore as positive teachings for the next generation of the nation so as not to lose ethics as a cultured and religious Indonesian society.

el Harakah Jurnal Budaya Islam Vol. 22 No. 1 Tahun 2020 


\section{Research Method}

The method used in this study was qualitative descriptions with content analysis. The primary source of this research is the text of the folklore in a collection of books called "Lampung Regional People's Stories" published by Departemen Pendidikan dan Kebudayaan Proyek Inventarisasi dan Dokumentasi Kebudayaan Daerah Jakarta in 1984. In the book" Cerita Rakyat Daerah Lampung" there are twenty folk stories from across the area in Lampung. This research takes one Tanggamus folk tale from the book as the focus, "Candung Kawik".

The data collection techniques in this study were library and logging studies. It is done by reading the text of the Candung Kawik repeatedly so that its content can be understood. There are also notes on matters related to the values of Islamic teachings found in the story of Candung Kawik.

The instruments used in this study were the researchers themselves with stationery and paper notes. Researchers as human instruments function to set the focus of research, conduct data collection, evaluate data quality, data analysis, interpret data and draw conclusions from their theory (Sugiyono, 2012).

The collected data were then analyzed by content analysis techniques. The primary purpose of content analysis is to draw conclusions based on existing data from a cultural phenomenon message (Endraswara, 2012). Furthermore, the data analysis was conducted by referring to the theory of Madjid (2000) which explained that the values of Islamic teachings included faith, Islam, ihsan, taqwa, sincere, tawakal, gratitude and patience. It makes easier to describe Islamic values that exist in Lampung Tanggamus folklore.

\section{Summary of Candung Kawik Folklore}

When Islam began to spread in Lampung, many people started converting to Islam especially in Semaka Gulf and Lampung Gulf. There is one person among many people in the area who is very obedient to the law and devout to Allah SWT, has good morals, is very talkative but he speaks to the heart of the listener. Many villagers seek advice and advice to Candung Kawik since his speech contains truth. Candung Kawik is not only famous in his area, but people from other areas know him. The benevolence and persistence of Candung Kawik can build an area along with other residents. The area is considered to be a fertile, peaceful and orderly village. No wonder so many people learn from him on how to become leaders and also to learn martial arts. 
One time the village where Candung Kawik lived was in disaster, the once fertile and peaceful village was ruined. Many villagers were devastated by the loss of trees and houses. Candung Kawik was sad seeing his village, he prayed to Allah for guidance and offered forgiveness. Later in the evening, after performing the prayer, Candung Kawik consulted with the residents at the village hall. He said that it is possible that he and the villagers committed many sins and were cursed by Allah. But he has been honest, well, doing all the commandments of Allah diligently.

The next morning at dawn, he said goodbye to the family and asked for a prayer of thanks before leaving. He walked along the Gulf of Semaka, walking without direction and purpose, his determination when he began to get tired then he stopped and his place will be used as a retreat. Candung Kawik then reaches the forest which is mostly overgrown with Cantigi trees. Because he was too tired, he fell asleep under a shady tree. In his dream, he met an old man who discovered the purpose of Candung Kawik. Therefore, Candung Kawik must be by his instructions to do asceticism for 45 days and 45 nights to meditate with monitor lizards with arms clasped in wood and straight legs. Then Candung Kawik woke up and realized what was happening just now. Finally, he started to do austerities.

The people left by the Candung Kawik started to panic, they always prayed to Allah for his safety and began to repair the damaged village. Not felt already 37 days Candung Kawik imprisoned, that was when the temptation of the most frightening demons and the most beautiful angels began to come. Still it did not shake the courage and obedience of his faith. The next day the venomous dragon snake came back and it rained for three days and three nights, which was still unable to shake his faith. Then on the last night, Candung Kawik was approached by the old man whom he met once in his dream.

The old man came to congratulate Candung Kawik for the strength he had gained and then disappeared. Halfway through the return of Candung Kawik, many chirping birds rejoiced over his success. Not felt already 45 days Candung Kawik did hermitage without eating and drinking, it was done with no tired or hungry at all.

On Candung Kawik's journey home, he began to feel the hot air and the wind was blowing very hard. It turned out that the form of the wind was the Wind Queen that had a cruel and sinister face. The Wind Queen wanted to kill him, but he quickly pounces on her neck. Finally, without any more resistance, the Wind Queen admitted to her defeat, apologized, and said her 
real name was Nyakhu. An a warrior, Candung Kawik forgave the mistake of the Wind Queen. Finally, they are friends and do not interfere with each other.

When Candung Kawik arrived at his village, the people were surprised. During the deliberations, Candung Kawik recounted all the incidents he had experienced while traveling and told him that he had gained the strength to fight the winds that had been disturbing the villagers. So far when residents hear the strong wind they say, "Let the wind pass, do not break. We are the Prophet Muhammad and the grandson of the Candidate, so the wind will soon go away.

\section{Islamic Teachings Values}

There are so many values of Islamic teachings that have been used as studies in various fields of research. The values of Islamic teachings that will be used as theories to study folklore in this study are faith, Islam, ihsan, taqwa, sincere, tawakal, gratitude, and patience. This theory was chosen because all the values of Islamic teachings exist by the teachings of Allah SWT in the Koran. Humans need to have faith, Islam, ihsan, taqwa to face life in the world. Humans also need to have a sincere attitude, trust, patience, and patience so that life becomes peaceful and focused. Therefore, the values of Islamic teachings need to be owned and taught by students from an early age to have the provision of religious teachings in future lives. The analysis is presented by first reading the "Ctandung Kawik" folklore, then looking for the values of Islamic teachings according to the order of the theories used and finally classifying the data taken from the "Candung Kawik" folklore into eight Islamic teaching values.

\section{The value of faith}

The results showed that faith shows how much human obedience to God. The value of Islamic teachings in the form of faith is in the story of Candung Kawik taught through the character of Candung Kawik himself. When he held a meeting for 45 days 45 nights, always came the temptation that began to bother him.

This can be seen in the original version of folklore published by Departemen Pendidikan dan Kebudayaan Proyek Inventarisasi dan Dokumentasi Kebudayaan Daerah Jakarta in 1984 page 22 as follows:

"Waktu terus berjalan, tak terasa sudah 37 hari Candung Kawik bertapa, waktu bertapa tinggal 8 hari. Saat itu mulailah datang godaan. Dari para setan yang paling 
menakutkan sampai para bidadari yang paling cantik menggodanya ia tetap tabah dan tak tergoyahkan imannya."

["Time continues to run, do not feel it has 37 days Candung Kawik imprisoned, only eight days remain ascetic. At that time the temptation began to come. From the scariest demons to the most beautiful angels teasing him he remains steadfast and unwavering in his faith."].

It shows that the faith of Candung Kawik is great, he is not tempted at all for the temptations given by the devil and angels. Candung Kawik is someone who has the principle that he will not be tempted by the form of any scary devil and beautiful angels. The excerpts from the Candung Kawik story also add to the understanding that his faith is strong:

"Godaan lain dengan munculnya ular naga berbisa akan menerkam Candung Kawik. Hujan selama 3 hari 3 malam tak menggoyahkan iman Candung Kawik."

["Another temptation comes with the appearance of poisonous dragons ready to pounce on their prey. Even the rain that comes for three days and three nights without stopping will not shake the faith of Candung Kawik."]

After the temptations of demons and angels came, again came the temptations of the serpents who have can be very deadly while rain continues without stopping. Candung Kawik remained steadfast in his stand, his faith was a little unwavering. He believes that God will protect him from any temptations and distress, as long as he obeys Allah SWT.

His belief is said in monotheism as in the Al-Uluuhiyah part that the oneness of God as a place of worship/service. Wherever Candung Kawik is, he has never left his worship as a Muslim.

"Malam hari sesudah sembahyang isya, ia pun mengadakan musyawarah dengan penduduk desa. Dengan perasaan yang berat ia pun mengutarakan maksudnya."

["At night after the evening prayer, he also held a meeting with the villagers. With a heavy feeling, he expressed his meaning."]

Although the duties and problems of Candung Kawik were burdensome at that time, he never left the command from his Lord, namely prayer. The village inhabited by Candung Kawik suffered a calamity in the form of strong winds that came to knock down trees and ransack villagers' houses. Therefore, Candung Kawik held a meeting with the villagers, community leaders. But before leaving for mediation, he carried out his obligations first as Muslims, namely prayer.

The inner attitude is full of trust in God in the monotheism of AlUluuhiyah not only in Candung Kawik, but also in the villagers who live right in Candung Kawik.

"Lain dengan penduduk desa yang telah ditinggalkan oleh Candung Kawik. Semenjak prahara itu terjadi semua penduduk mulai menata kembali desanya. Sehabis sembahyang

el Harakah Jurnal Budaya Islam Vol. 22 No. 1 Tahun 2020 
mereka berdoa mohon keselamatan dan tak lupa mendoakan Candung Kawik agar kembali dengan selamat"

["After Candung Kawik's reluctance to meditate, the villagers rearranged their homes that were damaged by strong winds. After praying they pray and ask for safety and do not forget to pray for Candung Kawik always to be healthy and return safely."]

The villagers also have strong faith. Since Islam came and spread to the Lampung area, many people began to learn about the teachings of the Islamic religion such as prayer, recitation, reading the Koran. It was done also by the villagers who did not forget to worship God and pray and ask for the safety of Candung Kawik.

\section{The value of Islam}

Islam is the rule of Allah revealed to the Prophet Muhammad to be disseminated to all humankind to be saved in the world and the hereafter. The rules are derived as a refinement of the previous regulations. Islam is reflected in the villagers and Candung Kawik.

"Dahulu sewaktu agama Islam mulai menyebar ke daerah Lampung, khususnya di pantai Teluk Semangka dan Teluk Lampung banyak penduduk yang mulai memeluk agama Islam"

["In the past, Islam began to spread to Lampung, especially in Semangka Bay and Lampung Bay. Many residents began to convert to Islam."]

It is illustrated that the villagers and Candung Kawik had converted to Islam after the Islam religion entered Lampung. It was once told that Lampung residents still believe in myths, still believe in mystical objects, believe in superstition to change because they have started to recognize Islam.

\section{The value of ihsan}

Ihsan is all human actions that are carried out like worshiping, as Allah is watching them. Worship solemnly that Allah is always watching his actions. Ihsan was in Candung Kawik when he got into a calamity and realized then he asked about whether he made a mistake to Allah.

"Ia berdoa mengadahkan tangan ke langit, meminta petunjuk dari Allah SWT. Kemudian ia bersujut meminta ampun Apakah dirinya dan penduduk telah berberbuat salah" ["He prayed to raise his hands to heaven, asking for guidance from Allah. Then prostrate asking forgiveness for all his actions so far. Whether he and the population made a mistake. May Allah forgive his sins."]

Candung Kawik realized that whatever he did could not be separated from the supervision of Allah SWT, so Candung Kawik begged forgiveness 
and asked about what sins he and the villagers had done to make Allah angry by bringing strong winds to damage his village. Whatever is done by living creatures created by Allah will not be separated from the supervision of Allah SWT.

"Dengan perasaan yang berat ia pun mengutarakan maksudnya. Mungkin aku dan ada penduduk desa kita ini yang melanggar ajaran dan hukum Allah hukum Allah" ["With a heavy feeling, Candung Kawik expressed his intentions. "Maybe I and the villagers here have violated Allah's teachings and laws,"]

Candung Kawik felt that he and the villagers had made a mistake so that God's law befell him and the villagers. That means Allah is always watching, watching whatever has been done by humans. Candung Kawik realizes this, that everything in the world is inseparable from the vision of Allah. Hence, he recognizes whether he has a mistake and violates what has been determined by Allah.

\section{The value of taqwa}

Taqwa has the meaning always to obey Allah SWT, carry out God's commands, and stay away from all its prohibitions. Candung Kawik has shown that he is always taqwa to Allah for all the teachings and prohibitions revealed from Allah SWT to the Prophet Muhammad to be carried out by all His people.

"Dari sekian banyak penduduk di daerah itu, ada seorang penduduk yang sangat taat kepada hukum dan di samping itu taqwa kepada Allah SWT."

["Of the many residents in the area, there is a resident who is very obedient to the law and is taqwa to Allah SWT."]

Since Islam entered the land of Lampung, especially in the Lampung Bay area there is someone who is God-fearing, he is Candung Kawik. He has a praiseworthy attitude, is honest and kind, always helps people who need help, and is modest. He does not talk much, said more meaningful, and always carries out worship like praying five times a day. Everyone was reluctant to him, most people came to ask for his advice. Thus Candung Kawik became famous, not only in his area but in other areas he began to be recognized by others. The nature of taqwa is also possessed by Candung Kawik when he is holding a meeting with the villagers to discuss a solution that is done so that no more disasters occur.

"Mungkin aku dan ada penduduk desa kita ini yang melanggar ajaran dan hukum Allah hukum Allah. Sehingga kita dikutukNya. Padahal aku telah berusaha berbuat sebaik mungkin, berbuat kejujuran, melakukan semua -perintahNya dengan tekun"

el Harakah Jurnal Budaya Islam Vol. 22 No. 1 Tahun 2020 
["Maybe there were some villagers and me who committed violations so we were condemned. Though I have tried to do my best, be honest, do all His commands diligently."]

Candung Kawik did the obedient attitude towards God. He said that Allah's commands had been carried out, but God still punished them by bringing calamity in the form of strong winds. That was said by Candung Kawik directly in front of the leaders, traditional leaders, and other villagers.

\section{The value of sincere}

Every action does not ask for compensation, all is done solely for the sake of Allah SWT, does not expect a reply from others, that is what is called sincere. Actions that have been carried out without coercion, everything is clear just to get the blessing of Allah SWT. Sincere performed by Candung Kawik when he helped the villagers after being exposed to strong winds, people's houses were damaged and fallen trees.

"Mereka bekerja membereskan desanya. Penduduk yang menderita luka-luka karena tertimpa pohon dan rumah, diobati oleh Candung Kawik. Bekerja dan bekerja tanpa mengenal lelah"

["They work to clear the village. Residents who suffered injuries due to falling trees and houses, treated by Candung Kawik. Work and work tirelessly."]

Candung Kawik does all that solely to get God's blessing. He did not expect a reply from those he had helped, he also helped tirelessly. Residents suffered injuries due to falling trees and ruins of houses. There is also the sincere attitude of Candung Kawik when fighting with the Wind Queen.

"Ia pun berkata 'Ku patahkan batang lehermu. Memang sengaja kau ku tunggu. Kau sombong dan telah berani merusak desaku. Kini apa maumu?' Ratu Angin tidak berkutik lagi dan ia meminta maaf kepada Candung Kawik. Ia juga menyebutkan namanya secara jelas bahwa ia bernama Nyakhu. Secara ksatria Candung Ka wi.k memperkenalkan diri dan mengampuni kesalahannya. Akhimya mereka bersahabat dan tak saling mengganggu"

["He also said 'I broke your neck, I deliberately wait for you. You are arrogant and have dared to disturb my village. Now, what do you want?' The Wind Queen did not move anymore and she apologized to Candung Kawik. In a warrior, Candung Kawik introduces himself and forgives his mistakes. Finally, they are friends and do not interfere with each other."]

The Wind Queen caused the riots that had occurred in the village where Candung Kawik lived. The Wind Queen also caused many fallen trees and damaged houses. He is an evil creature who likes to disturb humans, since Candung Kawik cannot be tempted, there is a great fight. He can defeat the Wind Queen, then she apologizes. Candung Kawik is a knight, so he forgave 
her and she promised not to disturb the villagers and descendants of Candung Kawik later.

\section{The value of tawakal}

Tawakal means giving everything to Allah SWT. It does not depend on anyone, both humans and other objects. Humans only try, the rest who decide is Allah SWT. Candung Kawik gave everything to Allah SWT for the disaster he experienced and the villagers.

"Desa yang teratur dan subur tak lagi tampak. Kini semua tinggallah puing-puing. Betapa pilu dan tersayat hati Candung Kawik melihat semua ini. Ia berdoa mengadahkan tangan ke langit, meminta petunjuk dari Allah SWT. Kemudian ia bersujut meminta ampun."

["An organized and fertile village is no longer visible. How sad and heartbroken Candung was married to see everything. He prayed to raise his hands to heaven, asking for guidance from Allah SWT. Then he pleaded for mercy."]

The village where Candung Kawik lived and other villagers were affected by a calamity in the form of strong winds. Candung Kawik is unable to do anything, just surrender to the almighty. He did not ask for help from other objects, only asking for help from Allah SWT. Because he believes that only God can help him and other villagers get out of the disaster.

\section{Gratitude Value}

An attitude of gratitude is a behavior of appreciation for what is given by Allah SWT, without asking for others. Whatever is in him, in front of him is a gift from Allah SWT. In Candung Kawik's story, he never asks for excessive things, nor do other characters. He is grateful for all the knowledge he gained when he was imprisoned, the knowledge that he could use to help villagers or others when they were having difficulties.

"Matahari bersinar dengan ceria. Burung-burung berkicau seakan-akan turut bergembira atas keberhasilan Candung Kawik"

["The sun is shining brightly. The birds chirping as if they were also happy for the success of Candung Kawik."]

Candung Kawik is a respected person, not only in his village but also respected by people outside the village. His goodness makes others reluctant. Not only humans, animals like birds join in the fun when they see him returning safely and at the same time gain knowledge to help others who are experiencing difficulties. 


\section{The value of patience}

Patience is an attitude of restraint from emotions and desires, and survive without complaining. Whatever is done with sincerity and can control himself in any situation.

"Tak terasa sudah 45 hari ia berada dihutan untuk bertapa tanpa makan dan minum.

Namun tiada Ielah atau lapar sedikit pun. Candung Kawik bersiap diri untuk turun. Ia akan pulang ke desanya."

["It feels like 45 days of Kawik Candung have been imprisoned in the forest without eating or drinking. But no tired and hungry at all. Candung Kawik prepares to come down and go home."]

The ascetic period of Candung Kawik was over. He did everything without complaining, full of sincerity, even though during his meditation he did not eat and drink. Candung Kawik can control himself during asceticism even though temptations come from the demon king, beautiful angels, and poisonous dragons. He continued his asceticism to gain strength to help those in distress.

\section{Discussion}

The first value is faith. The most important thing in Islam is to believe that Allah as God is worthy of worship, there is nothing that deserves to be believed except Allah, that attitude of trust is called Faith. Faith is believing and believing that Allah is One, spoken with words and done by deeds. Convinced that Allah is One in the Qur'an surah Al-Ikhlas verse 1 which reads "Say: 'He is the One Allah." The first lesson recognizes Allah where humans worship and ask for help wherever they are, words and deeds the same in one belief. Faith is a condition of being a Muslim, who is consistent throughout his life.

The value of Islamic teachings in the form of faith is found in the character of Candung Kawik in Lampung's folklore. The faith of Candung Kawik is unshaken even though the temptation comes from the most beautiful angels and ugly demons. The temptation comes when he conducts his hermitage for 45 days 45 nights. It is an example that in any situation Candung Kawik still holds fast to his Lord, he still believes that God always helps in any circumstance. Lampung folklore can be used as a media for the introduction of faith in students, the bias starts from the family, teachers, community. The most basic learning about monotheism begins with the family. Lubis (2016) said in the naming of monotheism that became a prominent example is a family, such as accustoming greetings, forgiveness, basmallah, performing prayers, fasting, zakat and so on. In addition to the family, teachers also become very 
important in preparing and educating the young generation with science, technology, and personality. So the teacher not only teaches science but also teaches about a noble character. Science as high as anything will not work without religion and belief in the One.

The next value is Islam as the religion that brings people to safety in this world and the hereafter, a religion full of peace, submission and cleanliness. Allah revealed Islam to the prophet Muhammad as a religion that is a mercy for all nature. In it, there are rules and guidelines for living to survive in this world and the hereafter.

Islam began to enter Lampung in the 15th century from Minangkabau, Palembang, and Banten. Once upon a time, Lampung residents were Hindus and Buddhists, after the clerics and scholars came to Lampung to spread the religion of Islam, Lampung residents began to embrace Islam and learn to worship such as reciting, praying, fasting. People in the Gulf of Lampung are learning religion and martial arts from Candung Kawik. The name Candung Kawik is famous not only in his village but also in other communities. Many residents come to learn from him because Candung Kawik is a person who is obedient to Allah, his behavior is outstanding, praiseworthy and modest. After Islam entered Lampung people began to abandon belief in objects, superstitions, and myths. The most influential are myths because myths can affect the worldview. Syaripulloh (2017) says that a myth can be valued as truth so that it can change the perspective of society, therefore the community does not dare to come out of the myths that already exist. But with the presence of Islam, people began to abandon everything they believed in from their ancestors.

Another value found is ihsan that has a meaning whatever is done by humans is always supervised by Allah. Likewise, Candung Kawik felt guilty and guilty, because his village had been damaged by the strong winds that came. He was very sorry and wondered if he had made many mistakes in his life so that Allah had destroyed the inhabited village. Cadung Kawik apologized to Allah for what he and other villagers had done by praying earnestly that Allah was watching over everything that happened in this world. It makes Candung Kawik and the community feel watched over whatever he does. Even though humans cannot see Allah, God can see what He created. It is written in the Koran surah Al-Fajr verse 14 that says "Verily, your Lord is watching". Worship and deeds performed by humans can all be watched by Allah because Allah is all-seeing.

el Harakah Jurnal Budaya Islam Vol. 22 No. 1 Tahun 2020 
The value of taqwa is also contained in the folklore. Religious humans should fear God, fear that they will fall into sinful acts so that they will consciously and sincerely carry out all the commands that Allah has given and stayed away from His prohibitions. Among the inhabitants of the Gulf of Semaka, there was a man named Candung Kawik who was fearful of Allah, he always carried out his orders and kept away from restrictions that could lead him to sin.

After the wind damaged the village incident, Candung Kawik felt the villagers and he had violated what his Lord had commanded. He also said in front of all the inhabitants, the customary leader, said that he had tried to do his best, be honest, like to help and do all the commands from God, but still the village where he lived had a disaster.

Candung Kawik folklore involves the value of sincere. Candung Kawik has a very sincere heart, helping fellow humans without expecting anything in return for merely obtaining God's blessing. He helped a lot of villagers due to the houses he lived in and the villagers were destroyed due to falling trees, many people were injured, Candung Kawik still helped without knowing tired.

Not only was he willing to help the villagers, but he also became a noble knight when he forgave all the mistakes of the Wind Queen that had made the village where he lived to fall apart. The Wind Queen is a creature that likes to disturb humans and mislead humans, but Candung Kawik does not have the slightest grudge, instead, he forgives the Wind Queen.

Tawakal's attitude is the attitude of surrender to Allah for all decisions received and keep trying as much as possible for the better. Candung Kawik surrendered everything that happened to God, asking for help and not begging for objects or other beliefs. He has tried his hardest and might to carry out Allah's commands and stay away from His prohibitions, but Allah willed others not following the wishes of Candung Kawik. Humans are ordered only to ask for help from God, may not ask with other objects or beliefs. Humans can only ask and try, the rest that determines success or not is Allah SWT.

Gratitude must be planted in the hearts of people to get God's blessing, accept all His gifts with pleasure, sincerely and do not ask for excessive. Usually, people forget to be grateful for Allah's thoughts so that they have thoughts that humans feel as if Allah has never given them something. Give thanks do not look over the favors given a lot or a little. The attitude of gratitude can be done with three things, namely by heart, oral and body. In Lampung's folklore, not only humans have an attitude of gratitude, but even animals have gratefulness 
to God. It is shown to the birds chirping as if happy to see Candung Kawik returning from his hermitage safely and getting the desired strength to help people who are experiencing difficulties. Even though there is no significant impact for the birds on his success to do hermitage, whatever is in this world is on God's will, so other animals are grateful for what he has seen.

Patience is done so that life is nobler, but patience is difficult to do. All trials that come in life must be done patiently, namely to refrain from lust, emotions, evil deeds that can plunge into sinful deeds. In life on earth, humans will never be separated by the name of a variety of problems, thus patience will be a controlling tool of all issues encountered. Patience is done to increase human obedience to his Lord. Persistence has been carried out by Candung Kawik by conducting austerities for 45 days 45 nights in a pitchblack cave. During that time, he did not eat or drink, run it with sincerity. Not only does he not eat and drink, but he also patiently faces temptations that come from demons and angels.

\section{Conclusion}

Lampung society has several folklore, one of them is Candung Kawik folklore in Lampung Bay. He is a man who is obedient to his Lord, always carrying out all the commands and avoiding his restrictions. These stories show the values of Islamic teachings namely faith, Islam, ihsan, taqwa, sincere, tawakal, gratitude, and patience. All values of Islamic teachings found are obtained from the attitudes and behavior of the characters in the story. It is by the attitude of Lampung people who are religious, diligent in worship, immediately ask for forgiveness if they make mistakes, help each other, have gratitude, and be patient in facing trials. After Islam entered Lampung, the community began to recognize Islamic teachings and renounce their beliefs, so that the people of Lampung lived side by side, having a culture of Islamic character. From here the values of Islamic teachings relate to Lampung culture such as always praying before starting traditional ceremonies, helping each other without expecting anything in return for farming, or building a house. Many Lampung people as social creatures tend to live together in the community, have the will, the mindset, to help and cooperate, to give birth to culture. Existing culture influences human behavior.

el Harakah Jurnal Budaya Islam Vol. 22 No. 1 Tahun 2020 


\section{References}

Al-Pansori \& Herman, W. 2014. Nilai-nilai pendidikan karakter dalam cerita rakyat Sasak (Pendekatan Pragmatik. Educatio, 9 (2), 9-23.

Damanhuri. 2010. Akhlak Tasawuf. Banda Aceh: Pena.

Djamal, S. M. 2017. Pelaksanaan nilai-nilai ajaran Islam dalam kehidupan masyarakat di desa Garuntungan Kecamatan Kindang Kabupaten Bulukumba. Adabiyah, 17(2), 9-23.

Endraswara, S. 2012. Metodologi Peneltian Kebudayaan. Yogyakarta: Gadjah Mada University Press.

Fauzi, M. S. 2006. Agama dan Kerukunan (Sebuah refleksi terhadap konflik antar pemeluk agama di Indonesia. El-Harakah, 8 (2), 217-227.

Gusal, L. 2015. "Nilai-Nilai pendidikan dalam cerita rakyat Sulawesi Tenggara karya La Ode Sidu." Humanika, 15(3), 1-18.

Hakim, Z. 2018. Struktur dan nilai-nilai kultural cerita Randa Wula'a. Sawerigading, 24 (1), 11-20.

Hartini, D. 2007. Masuknya Pengaruh Islam di Indonesia. Bandung: Pustaka.

Indiarti, W. 2017. Nilai-nilai pembentuk karakter dalam cerita rakyat asal-usul Watu Dodol. Jentera, 6 (1) 26-41.

Isnaeni, F. 2018. Pembudayaan agama dalam pembentukan karakter siswa di MTs Negeri Sleman Kota Yogyakarta. SAP (Susunan Artikel Pendidikan), $3(1), 33-40$.

Kristanto, M. 2014. Pemanfaatan cerita rakyat sebagai penanaman etika untuk membentuk pendidikan karakter bangsa. Mimbar Sekolah Dasar, 1 (1), $59-64$.

Kurnianto, E. A. 2016. Eksplorasi nilai-nilai luhur tradisi lisan Ngoni Cangkingan dalam adat perkawinan mayarakat Kayu Agung. Metasastra, 9 (1), 25-36.

Kurniawan, H. 2009. Sastra Anak dalam Kajian Strukturalisme, Sosiologi, Semiotika, Hingga Penulisan Kreatif. Yogyakarta: Graha Ilmu.

Madjid, N. 2000. Masyarakat Religius Membumikan Nilai-Nilai Islam Dalam Kehidupan Masyarakat. Jakarta: Pustaka Al-Kautsar. 
Mubarok, A. 2001. Psikologi Qur'ani. Jakarta: Pustaka Firdaus.

Muhammad, S. 2008. Fiqih E Tasawuf Wanita Muslimah. Surabaya: Cahaya Ilmu.

Nurfitri. 2018. Analisis nilai karakter dalam kumpulan cerita rakyat Aceh bernuansa damai. Master Bahasa, 6 (1), 56-66.

Prayitno, I. 2005. Kepribadian Muslim. Jakarta: Mitra Grafika.

Setyawan, A., Suwandi, S., \& Slamet, St. Y. 2017. Muatan Pendidikan karakter dalam cerita rakyat di Pacitan. Pendidikan Karakter, 7 (2), 199-211.

Shihab, M.Q. 2007. Ensiklopedia Alquran Kajian Kosakata. Jakarta: Lentera Hati.

Sugiyono. 2012. Metode Penelitian Kuantitatif Kualitatif dan R\&D. Bandung: Alfabeta.

Sukrawati, C.I. 2015. Nilai edukatif cerita “Be Jeleg Tresna Telaga”: Memperkuat pendidikan karakter bangsa. Aksara, 27 (2), 229-241.

Veronika, P., Budi, S., \& Nugraheni, E.W., 2017. Implementasi pembelajaran bahasa jawa (Materi Tembang Dolanan) berbasis pendidikan karakter religius dalam kurikulum 2013. el-Harakah, 19 (1), 53-77

Wiguna, M.Z., 2018. Analisis nilai-nilai moral dalam cerita rakyat Kalimantan Barat. Pendidikan Bahasa, 7 (1), 143-158.

Yayah. 2017. Nilai-nilai pendidikan dalam tradisi Islam Nusantara. Penelitian Penididikan Islam, 5 (1), 67-86.

Yunus, A. R. 2015. Nilai-Nilai Islam dalam budaya dan kearifan lokal (Konteks Budaya Bugis). Rihlah, 2 (1), 1-12.

el Harakah Jurnal Budaya Islam Vol. 22 No. 1 Tahun 2020 
